\title{
Current status, utilization, succession and zonation of mangrove ecosystem along Mida Creek, Kenya
}

\author{
MARY WANJIRU WARUI, SHYAM MANOHAR`, PAUL OBADE \\ School of Environmental Studies, Kenyatta University. P.O. Box 43844, Nairobi, Kenya. `email: prof.dr.smanohar@gmail.com
}

Manuscript received: 2 September 2019. Revision accepted: 14 February 2020.

\begin{abstract}
Warui MW, Manohar S, Obade P. 2020. Current status, utilization, succession and zonation of mangrove ecosystem along Mida Creek, Coast Province, Kenya. Bonorowo Wetlands 10: 32-43. Human activities have destroyed mangrove forests, posing a threat to the mangrove ecosystem and the living things that rely on it. From September 2009 through February 2010, researchers studied the current state, usage, succession, and zonation of the mangrove ecosystem along Mida Creek in Kenya's Coast Province. The goals were to assess changes in the floristic composition of the mangrove forest, identify the most preferred mangrove species, investigate whether accessibility determines utilization of mangrove species, investigate whether harvesting of mangroves affects their succession, and investigate the effectiveness of current mangrove forest management policies. The data was collected using the Point-Centered Quarter Method (PCQM) to see if access into the mangrove forest influences their use and affects mangrove succession. To evaluate the efficiency of government policies/legislation governing mangrove exploitation and the most favored mangrove species by the local community and other users, questionnaires were circulated, and interviews were conducted. Out of the 210 houses in Mida Creek, 136 respondents were interviewed, one from each household. To examine the temporal changes in the floristic composition of the mangrove forest, two sets of aerial images (1992 and 2006) were processed and interpreted. The data from the questionnaires were coded and entered into the Statistical Package for the Social Sciences (SPSS). An analysis of variance (ANOVA) was used to see if the accessibility of mangroves influences their use. To see if the utilization of mangroves affects their succession, researchers used regression analysis. To evaluate the forest structure, and importance value was derived. Descriptive statistics were used to summarize the present mangrove forest management policies and their effectiveness. Between 1992 and 2006, the floristic composition of the mangrove forest in Mida Creek changed; the area covered by mangroves decreased as follows: Rhizophora mucronata (Rm); 65.0963.93ha; Avicennia marina (Am); 344.99-310.63ha; Ceriops tagal (Ct); 225.12-223.82ha; Rm and Ct; 52.87-50.22ha; Ct and Am; 143.69- 140.29ha; Rm and Am; 44.36-41.27ha; Rm and Bg; 212.75-199.75ha; Rm and Sonneratia alba (Sa); 47.64-46.32ha; Rm, Ct and Bruguiera gymnorrhiza (Bg); 129.07-128.12ha; Rm, Am, Ct, and Bg; 472.44-428.46ha. The number of cut mangroves in the adjacent settlements, center, and shoreline revealed a significant difference $(\mathrm{F}=3.277 ; \mathrm{df}=2 ; \mathrm{p}=0.040)$ in the ANOVA test, indicating that accessibility determines consumption. The most favored mangrove species was Rhizophora mucronata, according to the findings. According to regression analysis, there was a correlation between the number of mangrove seedlings and the number of cut mangroves $(\mathrm{F}=8.529, \mathrm{df}=1, \mathrm{R}=0.198, \mathrm{P}=0.004)$. The use of mangroves has an impact on their succession. Mangrove utilization policies and legislation have been less effective. The key species in Mida Creek were Rhizophora mucronata and Ceriops tagal. The extent of mangrove forests in Mida Creek has shrunk over time.
\end{abstract}

Keywords: Mangroves, Mida Creek, status, succession, utilization

\section{INTRODUCTION}

Mangroves are woody tropical and subtropical trees or shrubs that grow in brackish seas or estuarine wetlands in the intertidal zone (Tomlinson 1986). Mangroves are found mostly in intertidal locations with groundwater discharges or seepage, not in estuaries (Ruwa and Polk 1986). In locations where there are no river discharges, this seepage is responsible for the colonization and growth of mangroves. The change in micro-environmental conditions from oceanic to brackish water caused by seepage of subterranean water to the shoreline creates acceptable micro-habitats for colonization by mangrove seedlings. It offers suitable habitats for suitable habitats mangrove development. This seepage is responsible for mangrove colonization and growth in locations with no river discharges. The change in micro-environmental conditions from oceanic to brackish water caused by seepage of subterranean water to the shoreline creates acceptable micro-habitats for mangrove seedling colonization and offers suitable habitats for mangrove development. Mangrove ecosystems are open systems that exchange matter and energy with the marine and terrestrial ecosystems that surround them (Manohar 1993).

Mangrove swamps are typical wetland habitats found along tropical and subtropical coasts in mud and silt deposits. These ecosystems are thought to cover 15.2 million hectares of the world's tropical shorelines (Spalding et al. 1997; FAO 2003, 2005). Mangrove forests provide critical functions and benefits to coastal zones and their plant, animal, and human populations as intertidal ecosystems (Cannicci et al. 2008; Kristensen et al. 2008; Nagelkerken et al. 2008; Walters et al. 2008). True mangroves (containing both major and minor components) and mangrove companions can be found in mangrove forests. True mangroves, according to Tomlinson (1986), 
are defined as species that have all or most of the following characteristics: (i) Complete fidelity to the mangrove environment; (ii) Play a significant role in forest structure and can form pure stands; (iii) Morphological specialization that adapts them to their environment (e.g., aerial roots and vivipary); (iv) Physiological mechanism for salt exclusion; (v) Taxonomic isolation from terrestrial relatives at least at the generic level. Mangroves are found worldwide, with 124 nations and territories containing mangrove species out of 258 (Tomlinson 1986; Saenger et al. 1983). In 1980, as part of the FAO/UNEP Tropical Forest Resources Assessment, the first attempt was made to estimate the entire mangrove acreage globally, estimated to be 15.6 million hectares. Mangrove coverage is now estimated to be 17,075,600 hectares (Aizpuru et al. 2000). Asia accounts for $38.51 \%$ of total mangrove coverage (FAO, 2005). Mangroves are mostly found between $30^{\circ} \mathrm{N}$ and $30^{\circ} \mathrm{S}$ latitudes. Japan $\left(31^{\circ} 22^{\prime} \mathrm{N}\right)$ and Bermuda $\left(32^{\circ} 20^{\prime}\right.$ $\mathrm{N})$ are the northern limits; New Zealand $\left(38^{\circ} 03^{\prime} \mathrm{S}\right)$, Australia $\left(38^{\circ} 45^{\prime} \mathrm{S}\right)$, and the east coast of South Africa (32 $\left.59^{\prime} \mathrm{S}\right)$ are the southern limits (Spalding et al. 1997). Mangroves are found along the warmer eastern coasts of the Americas and Africa instead of the cooler western coasts. The presence of warm and cold oceanic currents causes this disparity in distribution. The Eastern and Western hemispheres are the two main centers of mangroves (Duke 1992). The Indo-West Pacific region, which comprises East Africa, Indo-Malesia, and Australasia, is located in the Eastern hemisphere. The Atlantic East Pacific region encompasses West America, East America, and West Africa in the Western Hemisphere. Mangroves are thought to have originated in the eastern hemisphere, so the region is known as the Old World mangroves and the Western hemisphere as the New World mangroves. There are 49 mangrove species in the Eastern hemisphere and 11 in the Western hemisphere (Duke 1992). Indonesia, Australia, Brazil, and Nigeria have the most mangrove areas, accounting for 19.5, 9.2, 6.5, and 6.4 percent of global coverage, respectively (FAO 2007).

Mangroves can be found in nearly every country along Africa's west and east coasts, from Mauritania to Angola on the west coast and Egypt to South Africa on the east, including Madagascar and numerous other islands. They aren't found in Namibia, owing to the countries. Its semiarid, desert-like climate includes low and irregular rainfall, a lack of warming currents, and favorable topographical factors. Mangrove forests cover around 3.2 million hectares in Africa, accounting for roughly $19 \%$ of global coverage. They are found in three major coastal sections: the western Atlantic (1.5 million ha, 49\%), the central Atlantic (0.4 million ha, 14\%), and the western Indian Ocean (0.4 million ha, 14\%). (1.2 million ha, $37 \%)$.

In Africa, the phytogeographical distribution of mangrove species varies slightly across the continent. Avicenniaceae (Avicennia germinans, often known as white mangroves), Combretaceae (Laguncularia racemosa, Conocarpus erectus), and Rhizophoraceae (Rhizophora harrisonii, $R$. mangle, $R$. mucronata - usually called red mangroves) are three families comprising six species in West and Central Africa. In pure stands, especially in tidal estuaries, $R$. mucronata is very dominant in this location, characteristic of long and straight poles. $R$. harrosonii and $R$. mangle, respectively, are tiny trees and shrubs. There are ten species of mangroves in Eastern Africa, the most common being Rhizophora mucronata, Ceriops tagal, and Avicennia marina (Semesi 1998), which cover 1.1 million hectares (Spalding et al. 1997).

Mangrove forests can be found in Kenya's Coast Province, which runs along the Indian Ocean. Lamu, Ungwana Bay, Ngomeni, Malindi, Mida, Kilifi, Mombasa, Gazi, Funzi, and Shimoni are areas where mangrove forests may be found. Mangroves can be found as creek or fringe mangroves (Macnae 1968; Ruwa 1993). Mangrove trees that grow on low-gradient beaches in creeks and bays make up the creek mangrove community, which usually forms well-developed forests with species zonation. In front of or at the base of rocky cliffs, fringe mangroves grow solitary or in single or mixed species clusters. The most frequent mangroves along the Kenyan coast are creek mangroves, which form the pioneer population, spreading from the coastlines and colonizing mud banks in tributaries exposed at low tide.

Mangrove forests have been estimated to cover $75 \%$ of the world's tropical coasts. Because of anthropogenic pressures, the global range of these forests has shrunk to less than half of its original extent (Saenger et al. 1983, Spalding et al. 1997). According to a recent study of worldwide mangrove forests, the Eastern African region has lost around $8 \%$ of its mangrove cover in the last 25 years, or about 3,000 ha each year on average.

Plant biomass in mangrove forests has been shown to be up to $700 \mathrm{t} / \mathrm{ha}$, half of which is carbon. Tropical forest deforestation is thought to account for up to $17 \%$ of global carbon dioxide emissions, resulting in faster global warming (Van der Werf et al., 2009). The goals of this research were: (i) to evaluate the alterations in the floristic composition and structure of the Mida Creek mangrove forest between 1992 and 2006, (ii) to discover which mangrove species are the most common in Mida Creek, (iii) to see if the accessibility of mangrove species influences their use, (iv) to see if they use of mangroves has an impact on their succession, (v) to assess the efficiency of present mangrove forest management policies.

\section{MATERIALS AND METHODS}

\section{Study area}

Mida Creek $\left(3^{\circ} 21^{\prime} \mathrm{S}, 39^{\circ} 59^{\prime} \mathrm{E}\right)$ lies in the Malindi district, about $25 \mathrm{~km}$ south of Malindi town and $88 \mathrm{~km}$ north of Mombasa (Figure 1). The watercourse is located in a $31.6 \mathrm{~km} 2$ planographic area (Brakel 1979). Watamu Marine National Reserve in Mida Creek was designated as a protected area to recognize its scenery both above and below the water level. It is one of Kenya's three protected areas containing mangroves (Spalding et al. 1997). In 1968, it was designated as a reserve, and in 1976, it was gazetted under the Wildlife Conservation and Management Act. Watamu Marine National Reserve and the surrounding 
coast were declared as a Biosphere Reserve in 1979. (Kennedy 1988). Mangrove forests, sand flats, rock outcrops, seagrass beds, coral growths, and deep water make up the diverse habitats of Mida Creek. Natural elements such as mangroves, coral reefs, and mudflats may be found in reserve, serving as a haven for shorebird populations (UNEP/IUCN, 1988). Unlike most Kenya's coastal districts, Mida Creek receives no freshwater from overland sources.

\section{Climate}

The monthly temperature ranges from 23 to 27 degrees Celsius. The maximum temperature during the hottest times is $34^{\circ} \mathrm{C}$, while the minimum temperature is $20^{\circ} \mathrm{C}$. Strong winds, rougher water, and tidal flows during the south-eastern monsoon (April-September), known as the "Kusi," generate sea-grass deposits in some regions, particularly those bays facing that way. In the other months, the wind is calm. The average monthly wind speed is $9.6 \mathrm{~km} \mathrm{hr}-1$, with a range of $6.2 \mathrm{~km} \mathrm{hr}^{-1}$ to $16.6 \mathrm{~km} \mathrm{hr}^{-1}$. The total yearly precipitation ranges from 1000 to 1600 millimeters. The long rains, influenced by southeast monsoon winds, fall from April to June, while the short rains fall between November and December. The area is generally hot and humid, with an average yearly air temperature of around $28^{\circ} \mathrm{C}$ and minimal seasonal change. Because of the close proximity to the sea, relative humidity is about $95 \%$.

\section{Geology of soils}

Coral limestone rock, shallow sandy clay soils, fringing reefs, and coral gardens are all characteristics of Mida Creek. Mida Creek has a low water-retention capacity.

\section{Socio-economic activities}

People in the Mida Creek area generate income by trading coconuts and mangoes and building materials such as mangrove poles, bricks, gravel, and cement. They also create and sell tourist trinkets and souvenirs. Some members of the community work as tour guides, while others operate boats that transport tourists around scenic areas for a fee. The majority of the residents are fishers who sell seafood to supplement their income. The community owns some bandas that tourists use, which they profit from. Mida Creek has a population of about 30,000 people, with literate residents accounting for half of that.

\section{Mangrove vegetation}

Mida Creek is home to eight of the ten mangrove species discovered in Kenya (Kokwaro 1985), occupying a total area of 1746 ha (Gang and Agatsiva 1992; Kairo and Gwada 1998). Avicennia marina, Rhizophora mucronata, Ceriops tagal, Lumnitzera racemosa, Bruguiera gymnorrhiza, Sonneratia alba, Xylocarpus granatum, and Pemphis acidula are the mangrove species found near Mida Creek. Rhizophora mucronata, Ceriops tagal, and Avicennia marina are the most common species (Tomlinson 1986). Numerous researches, including some coastal research, have been undertaken in and around Mida Creek (Ouko and Manohar 1998).

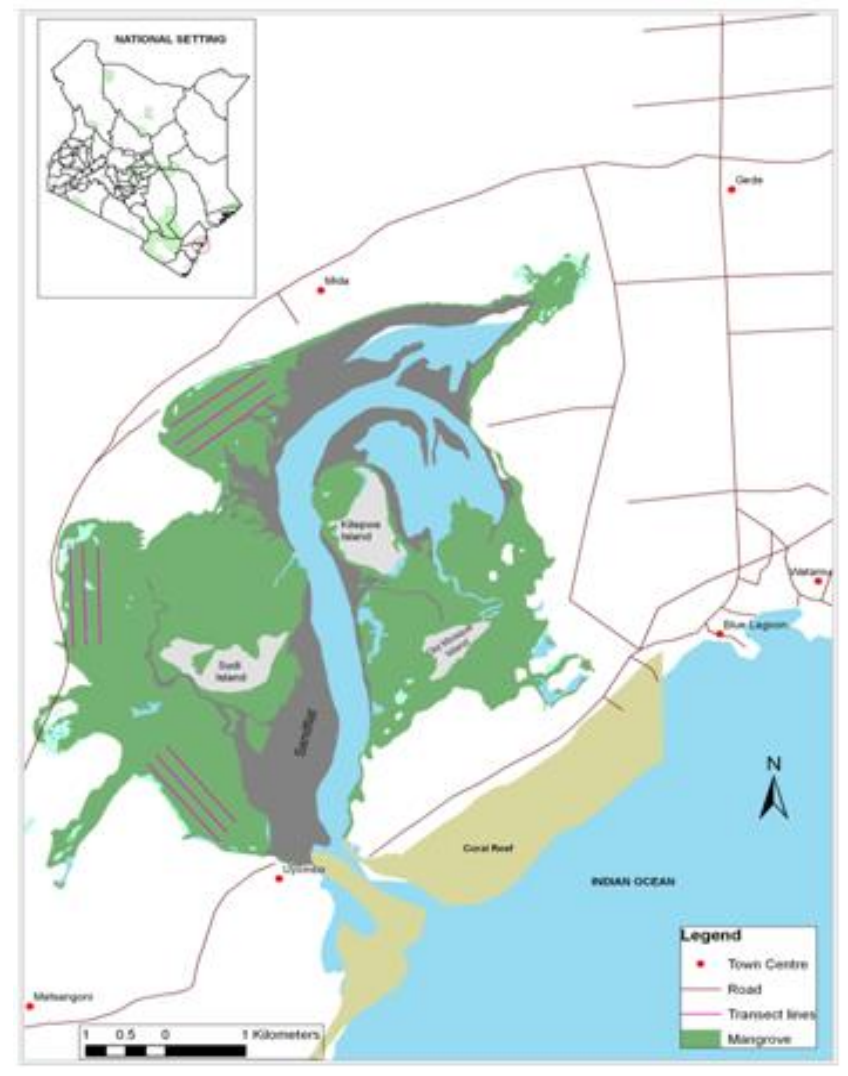

Figure 1. A map showing the study area (Mida Creek), Coast Province, Kenya

\section{Data collection}

In this study, data was gathered from both primary and secondary sources.

\section{Secondary data}

Secondary sources such as textbooks, journals, economic surveys, government and nongovernmental organization reports, academic research findings, and media coverage provided the initial information and data. After that, the secondary data were combined to create information on various topics, including the socioeconomic situation, the current state of mangroves, governance, policies, and management techniques.

\section{Primary data}

Interviews, questionnaires/surveys, direct observation, satellite imagery, and participant observation were all used to collect primary data. Initially, exploratory field surveys were done in the study site, followed by creating questionnaires for data collection.

\section{Aerial photographs/Visual image interpretation}

To examine the temporal changes in the floristic composition of the mangrove forest in Mida Creek, two sets of a combination of 12 aerial pictures for each set, showing the forest's condition in 1992 and 2006, were utilized. Aerial photos from the Kenya Marine Fisheries Institute (KEMFRI) were obtained in 2006, while aerial photos from the Survey of Kenya and the Kenya Wildlife Service were taken in 1992 . Aerial pictures were scaled at 
1:35,000 and 1:25,000, respectively. The aerial photos were scanned and saved as jpeg files. After that, visual interpretation employed texture, shape, tone/color, and pattern. Bare patches, islands, mangroves (species level), and oceans were recognized as four different types of cover. Eleven classes of the identified mangroves were: Rhizophora mucronata; Avicennia marina; Ceriops tagal; Sonneratia alba; a mixture of Rhizophora mucronata and Ceriops tagal; a mixture of Ceriops tagal and Avicennia marina; a mixture of Rhizophora mucronata and Avicennia marina; a mixture of Rhizophora mucronata and Bruguiera gymnorrhiza; a mixture of Rhizophora mucronata and Sonneratia alba; a mixture of Rhizophora mucronata, Ceriops tagal and Bruguiera gymnorrhiza and a mixture of Rhizophora mucronata, Avicennia marina, Ceriops tagal, and Bruguiera gymnorrhiza. Onscreen interpretation, in which the visuals are zoomed in and out for clearer visibility, was used for a more detailed and in-depth explanation.

The photos were georeferenced using the fiducial markers that had already been marked on the aerial photographs as control points. Five sampled points were taken for each class of species identified, and the coordinates were uploaded to the GPS ready to place on the ground. To reduce overlaps during ground crossings, the sampling point was selected at an interval of $50 \mathrm{~m}$. The sampling points were also representative for each class to avoid distortions, and the sampling points were distributed uniformly for each class. There are a total of 55 points taken. During ground-truthing, sampling spots were established using GPS, and observations were made in a $10 \mathrm{~m}$ radius, with the species found are recorded. The classes were corrected when there was a discrepancy between the classes determined during photo interpretation and what was discovered on the ground.

The final classes were then digitized onscreen with ArcGIS version 9.3, which resulted in different shapefiles for each number of classes. Mangroves, bare patches, and island cover types have their respective area coverages determined. When comparing the changes between the two time periods, some modeling was done. The same cover types from the two years were intersected, and the area outside the intersection was used to determine the extent of change.

\section{Questionnaires, interviews, and observations}

Questionnaires and interviews were used to analyze the effectiveness of policies/legislation guiding mangrove exploitation and learn more about the most desired species. The total number of homes in the Mida Creek area is 210 (less than 10,000); hence the sample size was 136. This was calculated using Fisher's equation (Fisher et al. 2004).

$$
N=\frac{Z^{2}(p)(q)}{d^{2}}
$$

Where:

$\mathrm{Z}$ refers to the confidence limits of the survey results. If one would like to be $95 \%$ confident in your results, $Z=1.96$ prefers to the proportion of the population with the attribute you are looking for

$q=(1-p)$

$\mathrm{d}$ refers to the desired precision of the estimate

Data was gathered by interviewing 136 people in the Mida Creek area. Questionnaires were completed, and visual observations of daily life in the homes visited were made. One hundred people from the houses and thirty-six Kenya Forest Service and Kenya Wildlife Service staff members were questioned, resulting in 136 questionnaires used for numerical analysis. To avoid repeating questions from members of the same home, just one individual per household (the head of the family) was questioned. Because of the unavailability of topographic or administrative maps showing household distribution, households were approached directly in the field. Uyombo, Chafisi, Mida Msikitini, Mida Majaoni, Magangani, and Dongokundu were the locations of the interviews using stratified random sampling. The interviews were conducted in Kiswahili and/or the native Giriama, depending on the respondents' comfort level with each language. The old preferred to speak in Giriama, while the middle-aged and youth favored Kiswahili. A Kenya Wildlife Service guide, Gede, and a local resident aided in traveling around the creek, eliminating potential antagonism and allowing for a comfortable reception and fluent dialogue with the respondents in the visited families. The data was then entered into questionnaire schedules.

The questionnaire included questions to gather general information about the respondents, elicit the respondents' opinions on various issues, and reveal "the way of forest life" of the community members, i.e., how they used the mangrove forest and what kind of preferences they had. The questionnaire was semi-structured, with brief multiplechoice and some open-ended questions. The former primarily focused on narrowing down the answer categories to make data analysis easier. To ensure that the respondent and interviewer discussed the same concept and subject area, the interviews frequently began examining the respondent's comprehension of the term mangrove and how the trees look (distinguishing them from other trees). Mangrove trees were given the name mkoko, which was a Kiswahili or Giriama phrase, although only one species (Rhizophora mucronata or red mangrove) was called mkoko at the species level.

When respondents were afraid of answering specific questions because they were participating in certain behaviors, eye observation was used to obtain the necessary information (e.g., use of mangroves as poles which was easily visible). In other cases, observations were required to visually examine and complete the respondents' responses. Mangroves were used for various purposes, including furniture, cooking utensils, fishing traps, canoes, sailboats, and the construction of dwellings. The amount of the mangrove species cut was clearly evident. This method of observation supplemented the information obtained during the interviews. The few concerns that arose during the survey had to do with the sensitivity of specific topics. Given the present policy on mangrove exploitation in 
Kenya, the issue has become sensitive. Questions on mangrove pole harvesting elicited a lot of skepticism, making it difficult to get information from respondents. This is because no permits for mangrove harvesting are provided in Mida Creek. It often needed a long chat to gain the respondent's trust and make them feel comfortable enough to answer questions. Community leaders were seeking to gather sensitive information. The Kenya Forest Service, Kenya Wildlife Service, and Kenya Forestry Research Institute staff were given questionnaires. Personal contact was also established with the District Forest Officer and the KWS senior warden in charge of Gede. The questions posed aided in determining the efficacy of mangrove conservation strategies and regulations.

\section{Point-Centered Quarter Method (PCQM)}

Transects and sampling locations were utilized to analyze the impacts of mangrove utilization/harvesting on mangrove succession, mangrove forest structure, and if mangrove accessibility determines their utilization Figure 2). Three $200 \mathrm{~m}$ long line transects were created perpendicular and parallel to each other (along with the land, near the coastline, and in the middle). The distance between each transect was 100 meters. The Point-Centered Quarter Method (PCQM) was utilized, and vegetation sampling was done in $100 \mathrm{~m} 2$ quadrats that were regularly spread out along the transects. Each transect had ten quadrats set out. In Mida Creek, seven replicates, thus 210 quadrats, were studied. This took place for over a month.

The transect was laid out with a tape measure, and the transects were marked with red tape. A compass and a GPS were used to guarantee that the transect fell in a straight line. If the mangrove roots were too large or a tree blocked the transect, a way was found to get around them, but the straight line was maintained once on the other side. To make data collecting easier and to avoid danger, a tide table was checked every day to determine the times of low and high tides. GPS coordinates and altitude were recorded in each quadrat. Mangrove species were classified, and the number of standing trees $(>4 \mathrm{~cm} \mathrm{DBH})$, cut stems, dead trees and stems, and seedlings/saplings were also tallied (below $4 \mathrm{~cm} \mathrm{DBH).} \mathrm{This} \mathrm{was} \mathrm{accomplished} \mathrm{by} \mathrm{visual}$ observation. The diameter at breast height (D130) was measured and recorded using a tape measure. All of the trees whose DBH was measured had their canopy cover approximated. All of the trees whose DBH was measured had their canopy cover compared. Following the procedures described in Cintron and Novelli (1984) and Kairo et al., the following characteristics were determined: stem density (De), frequency $(\mathrm{F})$, basal area $(\mathrm{Ba})$, and importance value (IV) (2002). Photographs were taken in some of the quadrats where most of the trees had been damaged or scattered.

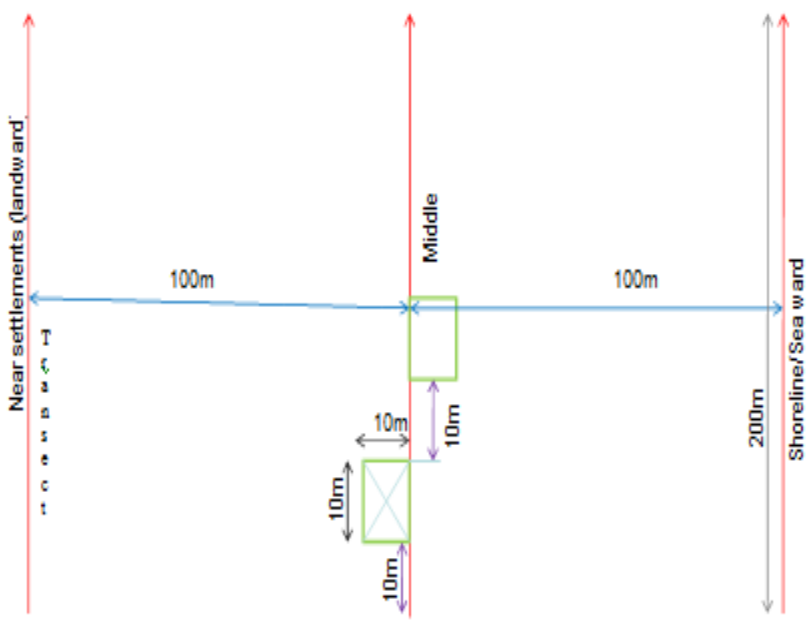

Figure 2. A transect layout for Point-Centered Quarter Method (PCQM)

The following formulas were used to compute relative density, relative dominance, relative frequency, and Importance Value: The relative density $\left(D E_{\mathrm{ri}}\right)$ was;

$$
D E_{r i}=\frac{100 D E_{i}}{\sum_{i=1}^{m} D E_{i}}
$$

Where: $D E_{\mathrm{i}}$ was the density for species $I$, and $m$ is the number of species. The relative dominance $\left(D O_{\text {ri }}\right)$ was;

$$
D O_{n i}=\frac{100 B a_{i}}{B a} \text {, }
$$

Where: $B a_{\mathrm{i}}$ was the basal area of all trees of species $i$. The relative frequency $\left(F_{r i}^{\prime}\right)$ was;

$$
F_{n i}^{\prime}=\frac{100 F_{i}}{\sum_{i=1}^{m} F_{i}},
$$

Where: $F \mathrm{i}$ was the number of sampling points in which species $i$ is represented 100 times. The importance value (IV) was calculated as;

$$
\mathbf{I V}=\mathrm{DE}_{\mathrm{ri}}+\mathrm{DO}_{\mathrm{ri}}+\mathrm{F}_{\mathrm{ri}}
$$

\section{Data analysis}

For data analysis, the completed questionnaires were coded and imported into SPSS. To examine if the use of mangroves affects their succession, researchers used regression analysis. The difference between the means in the number of cut mangroves in three different zones was assessed using analysis of variance (ANOVA) to see if the accessibility of mangroves affects their usage. To analyze changes in the floristic composition of the mangrove forest in Mida Creek, aerial pictures were georeferenced and visually assessed. Descriptive statistics were used to summarize data on awareness and effectiveness of policies governing mangrove exploitation. According to Dahdouh- 
Guebas and Koedam, relative density, dominance, and frequency were calculated, and importance levels were assigned (2006). This was used to evaluate the structure and regeneration of mangrove forests.

\section{RESULTS AND DISCUSSION}

\section{Mangrove knowledge levels}

When interviewing the respondents, different levels of knowledge became apparent. Using different physiognomic and morphological aspects of the plants (e.g., roots, leaves, bark) and their environments, the 136 respondents were able to identify mangrove species (where mangroves are found).

Knowledge of mangroves was unaffected by education levels (none, primary, secondary, college, and university). Although the roots, leaves, and bark of mangroves could be distinguished from those of other trees, the majority of respondents described mangroves based on their habitat (those that grow in salty water or the ocean) (Figure 3 ).

The respondents had no trouble answering the questions during the interview and filling out the surveys because they understood precisely what mangroves were and how they looked. Some people could tell the difference between all mangrove species, while others could only say the difference between a few.

\section{Accessibility and utilization}

The ANOVA test revealed a significant difference in the mean number of cut mangroves in three areas: near settlements, middle, and shoreline (Most accessible, middle, and least accessible, respectively) $(\mathrm{F}=3.277$; $\mathrm{df}=2$, 207; $\mathrm{p}=0.040$; (Table 1). Because mangrove species are more accessible (i.e., they may be entered without trouble), they are used more near communities and the seashore.

The number of cut trees nearest settlements and in the shoreline was higher than in the middle (Figure 4).

\section{Mangrove forest structure at Mida Creek}

Rhizophora mucronata and Ceriops tagal were the important species in Mida Creek, based on relative density, relative frequency, relative dominance, and significance values (Table 2). Mida Creek was the most structurally developed mangrove forest, followed by the Avicennia marina.

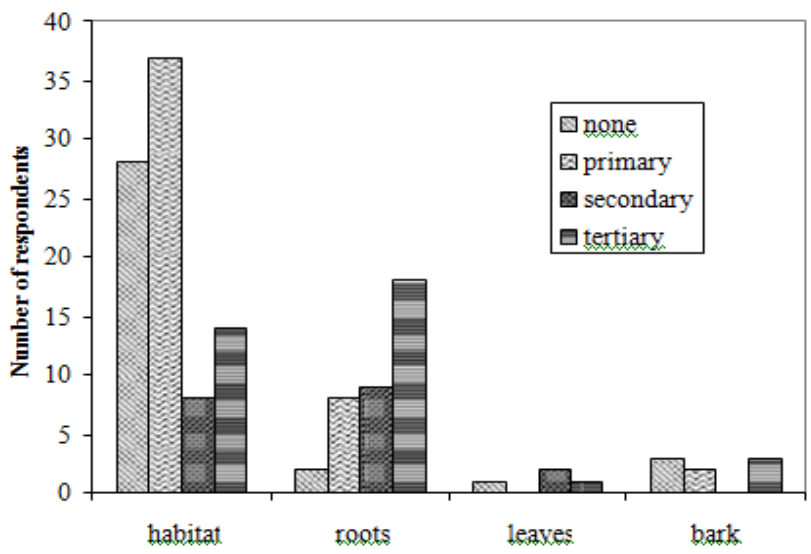

Figure 3. Mangrove knowledge levels by the local community

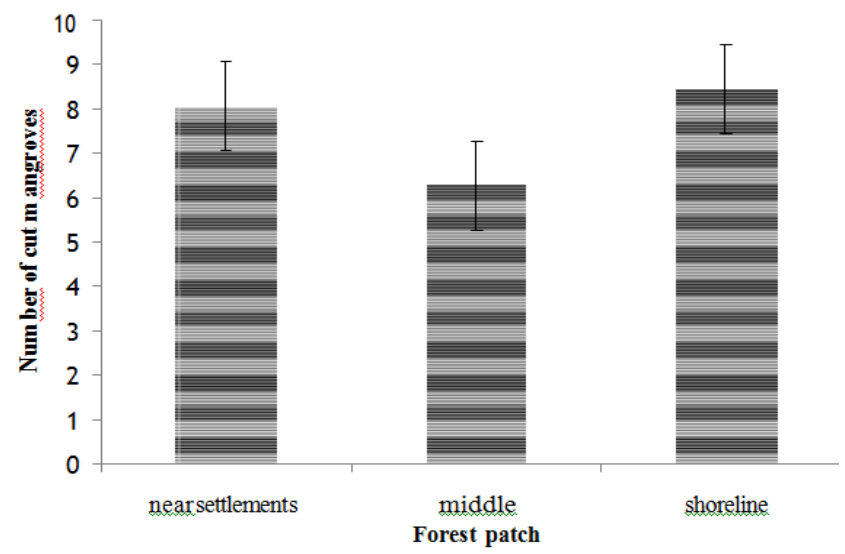

Figure 4. The abundance of cut mangroves in each forest patch

Table 1. ANOVA for accessibility and utilization for the number of cuts

\begin{tabular}{lllllll}
\hline & Ss & df & Ms & F & P \\
\hline Forest & & & & & \\
patches & 205.895 & 2 & 102.948 & 3.277 & 0.04 \\
Error & 6503.729 & 207 & 31.419 & - & - \\
Total & 6709.624 & 209 & - & - & - \\
\hline
\end{tabular}

Note: Ss: Sum of squares, df: degree of freedom, Ms: Mean square, F: calculated f value, $\mathrm{P}$ : significant value

Table 2. Structural attributes of the mangrove species at Mida Creek, North Coast, Kenya

\begin{tabular}{lllllllll}
\hline \multicolumn{1}{c}{ Species } & \multicolumn{1}{c}{ Density } & Frequency & Dominance & R/density & R/frequency & R/dominance & IV & IV/3 \\
\hline Avicennia marina & 729.5 & 0.2762 & 0.000308 & 9.88 & 17.68 & 23.83 & 51.39 & 17.13 \\
Rhizophora mucronata & 3201.0 & 0.7048 & 0.000478 & 43.37 & 45.12 & 36.95 & 125.44 & 41.81 \\
Ceriops tagal & 3164.8 & 0.4619 & 0.000400 & 42.88 & 29.57 & 30.97 & 103.43 & 34.48 \\
Bruguiera gymnorrhiza & 137.6 & 0.0476 & 0.000031 & 1.86 & 3.05 & 2.40 & 7.32 & 2.44 \\
Sonneratia alba & 118.1 & 0.0571 & 0.000064 & 1.60 & 3.66 & 4.92 & 10.18 & 3.39 \\
Xylocarpus granatum & 20.0 & 0.0095 & 0.000010 & 0.27 & 0.61 & 0.75 & 1.63 & 0.54 \\
Lumnitzera racemosa & 9.5 & 0.0048 & 0.000002 & 0.13 & 0.30 & 0.18 & 0.61 & 0.20 \\
\hline
\end{tabular}

Note: Density: Species/ha, Frequency: Proportion of subsamples which contain species, Dominance: basal area of species by total area $\left(\mathrm{m}^{2} / \mathrm{ha}\right)$, Relative density, frequency, dominance, importance value: in percentage $(\%)$. 


\section{Mangrove forest cover at Mida Creek}

According to $\tan \mathrm{o}$ an aerial photography study, the extent of mangrove vegetation in Mida Creek has shrunk between 1992 and 2006. Mangrove forest has been lost in an area of 105.217 hectares, while bare patches and islands have risen by 32.098 ha and 107.44 ha, respectively (Table 3 ). Islands and bare patches acquired a total of 139.538 square kilometers. This is due to human activities, which have resulted in islands and bare patches extending into the mangrove forest. They've also reached out to the sea. Mangrove plants were present in several areas in 1992 but were not visible in 2006. (Figures 5 and 6).

Table 3. Changes in mangrove forest cover at Mida Creek (19922006)

\begin{tabular}{lccc}
\hline & $\begin{array}{c}\mathbf{1 9 9 2} \\
\text { (area in ha) }\end{array}$ & $\begin{array}{c}\mathbf{2 0 0 6} \\
\text { (area in ha) }\end{array}$ & $\begin{array}{c}\text { Area } \\
\text { (ha) }\end{array}$ \\
\hline Mangroves & 1745.545 & 1640.328 & $105.217(-)$ \\
Bare patches & 52.193 & 84.291 & $32.098(+)$ \\
Islands & 165.725 & 273.165 & $107.44(+)$
\end{tabular}

Note: +: gained, -: lost

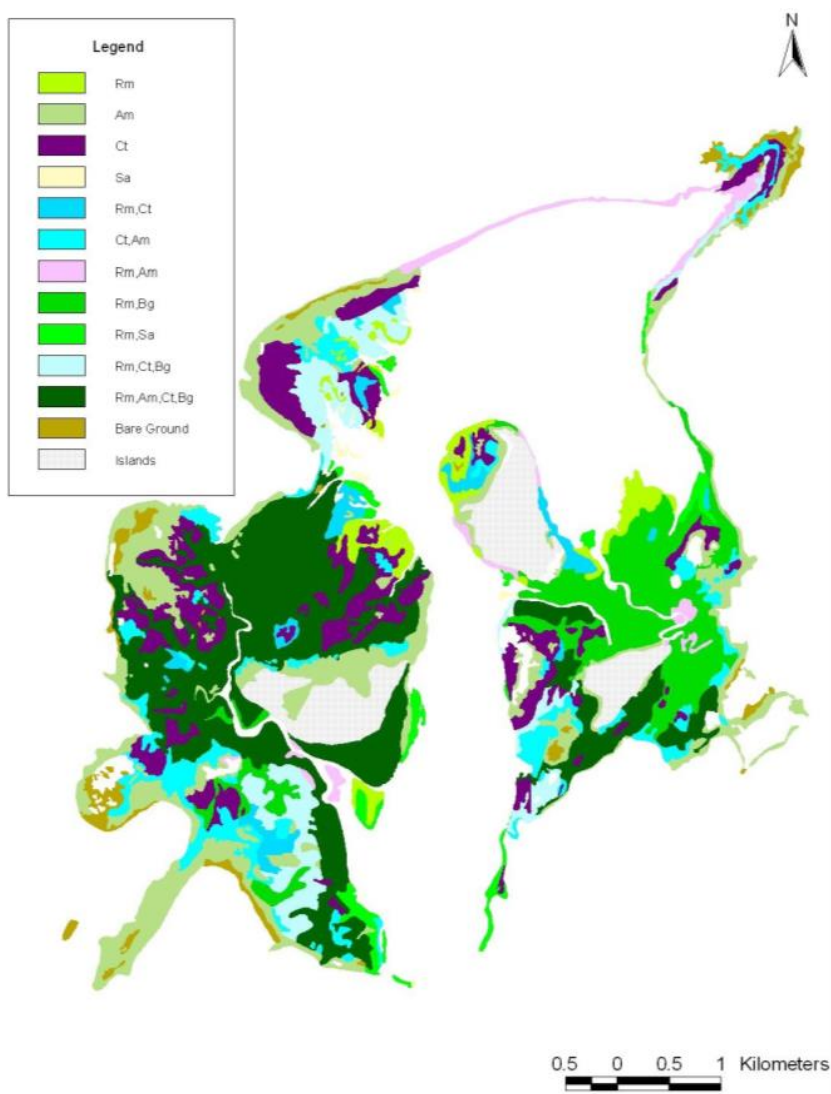

Figure 5. Aerial photograph interpretation showing the floristic composition of mangrove forest in Mida Creek in 1992
According to the findings, the area occupied by different mangrove species in Mida Creek, Kenya, has altered over time (Table 4).

Clearing/felling of trees and encroachments have caused alterations in the mangrove forest in some areas (Figure 7).

Table 4. Floristic composition and changes in the area of mangrove forest at Mida Creek (1992-2006)

\begin{tabular}{lccc}
\hline $\begin{array}{c}\text { Mangrove } \\
\text { Species }\end{array}$ & $\begin{array}{c}\text { Coverage in Ha } \\
(\mathbf{1 9 9 2})\end{array}$ & $\begin{array}{c}\text { Coverage in Ha } \\
(\mathbf{2 0 0 6})\end{array}$ & $\begin{array}{c}\text { Difference } \\
\text { (ha) }\end{array}$ \\
\hline $\mathrm{Rm}$ & 65.088 & 63.934 & 1.154 \\
$\mathrm{Am}$ & 344.986 & 310.627 & 34.359 \\
$\mathrm{Ct}$ & 225.116 & 223.821 & 1.295 \\
$\mathrm{Sa}$ & 7.529 & 7.529 & - \\
$\mathrm{Rm}, \mathrm{Ct}$ & 52.874 & 50.219 & 2.655 \\
$\mathrm{Ct}, \mathrm{Am}$ & 143.693 & 140.287 & 3.406 \\
$\mathrm{Rm}, \mathrm{Am}$ & 44.359 & 41.270 & 3.089 \\
$\mathrm{Rm}, \mathrm{Bg}$ & 212.751 & 199.747 & 13.004 \\
$\mathrm{Rm}, \mathrm{Sa}$ & 47.642 & 46.321 & 1.321 \\
$\mathrm{Rm}, \mathrm{Ct}, \mathrm{Bg}$ & 129.066 & 128.117 & 0.949 \\
$\mathrm{Rm}, \mathrm{Am}, \mathrm{Ct}, \mathrm{Bg}$ & 472.441 & 428.456 & 43.985 \\
\hline Note: $\mathrm{Rm}:$ Rhizophora mucronata, Am: Avicennia marina, Ct: \\
Ceriops tagal, Sa: Sonneratia alba, Bg: Bruguiera gymnorrhiza
\end{tabular}

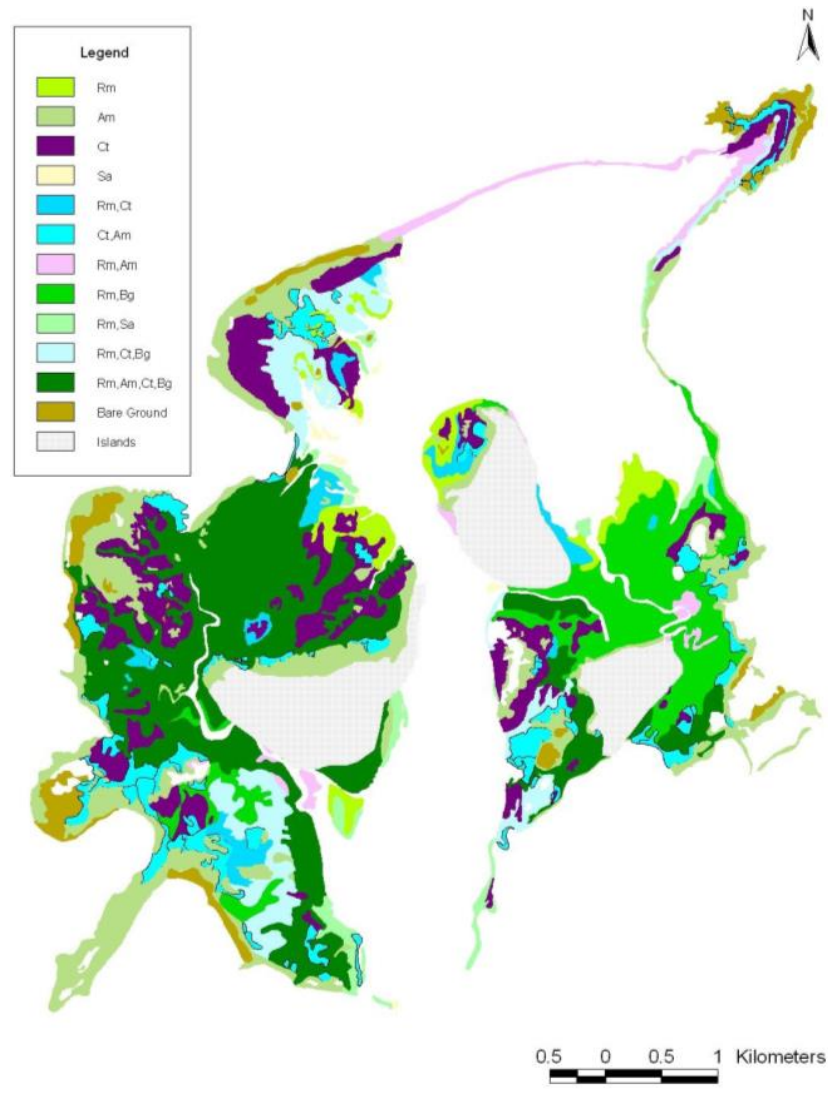

Figure 6. Aerial photograph interpretation showing the floristic composition of mangrove forest in Mida Creek in 2006 


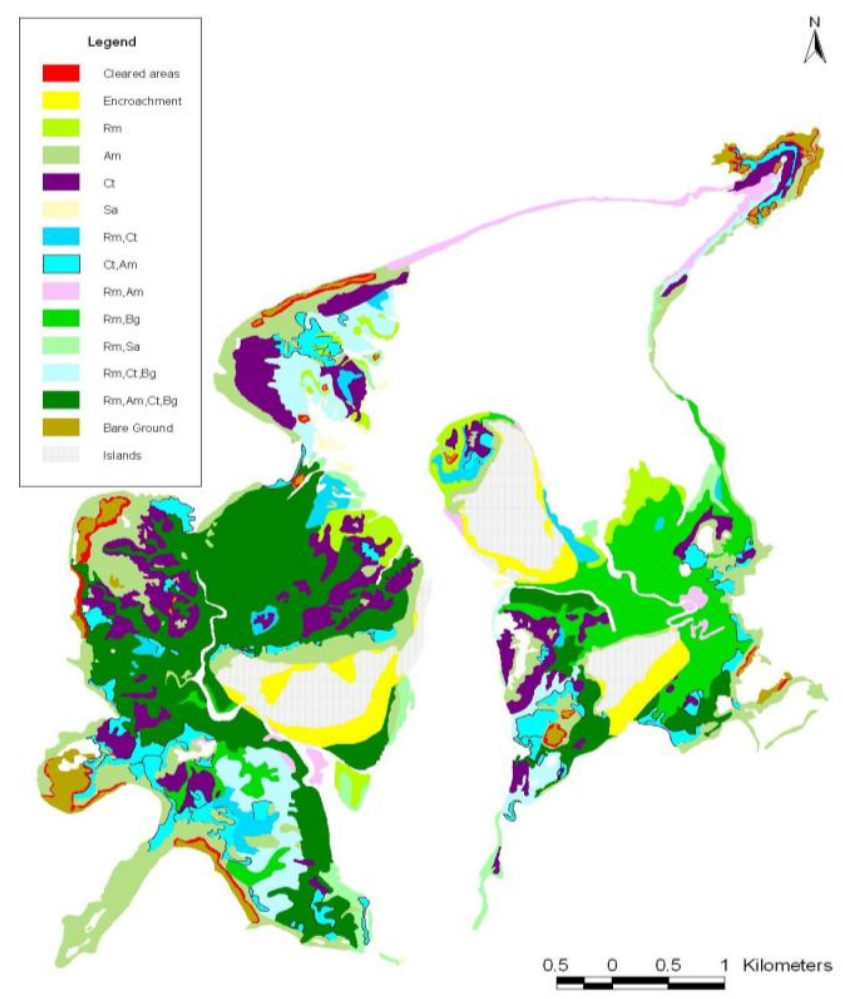

Figure 7. Aerial photograph interpretation showing changes in the floristic composition of mangrove forest in Mida Creek (19922006)

Alterations in the mangrove forest in Mida Creek up to the time of data collection were supported by questionnaires, with the majority of respondents stating that the mangrove forest in Mida Creek has reduced over time (Figure 8).

\section{Mangrove preferences}

Some mangrove species are more desirable than others. Rhizophora mucronata is the most popular species in Mida Creek due to its high-quality wood, followed by Ceriops tagal and Avicennia marina by both males and females (Figure 9).

\section{Awareness of policies and legislation}

In both sexes (Figure 10), people of all ages, occupations, education levels, and length of stay are aware of mangrove utilization policies. The policies are unknown to a few people.

\section{Succession and utilization}

Regression study revealed a significant association between mangrove succession and utilization $(\mathrm{F}=8.529$, $\mathrm{df}=1, \mathrm{R}=0.198, \mathrm{P}=0.004$ ) (Table 5). As a result, there existed a link between succession and utilization. The use of mangroves has an impact on their succession. In extensively used areas, natural succession was low (Figure 11). The number of chopped stumps could only explain $4 \%$ of the variation in the number of saplings, according to $\mathrm{R} 2=0.0392$.

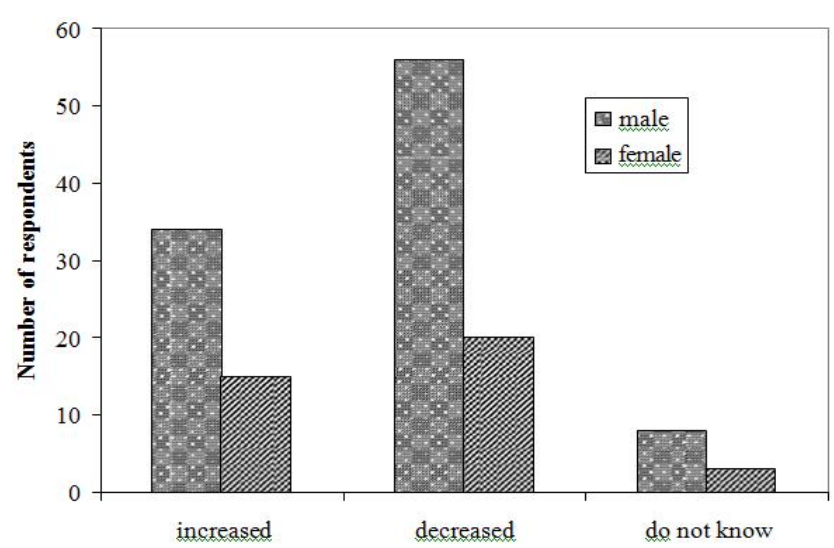

Figure 8. Awareness of changes in the mangrove forest cover along Mida Creek

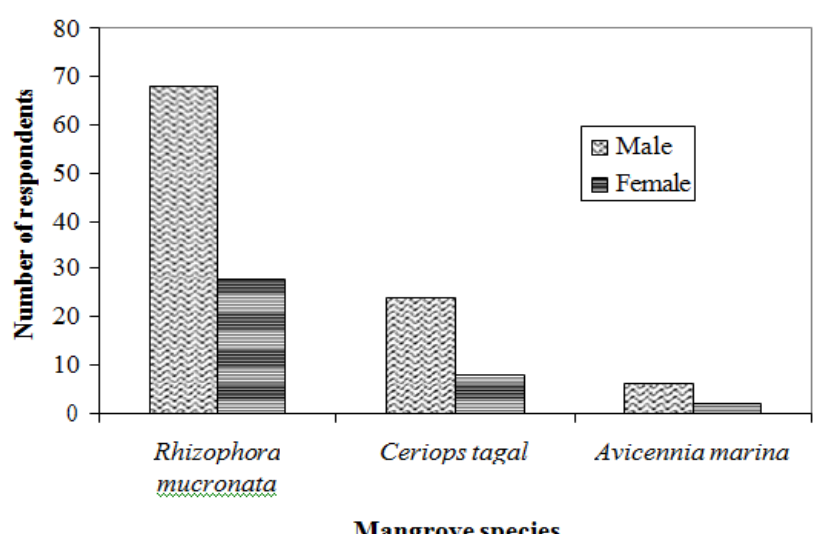

Figure 9. Preference of mangrove species by sex of respondents at Mida Creek

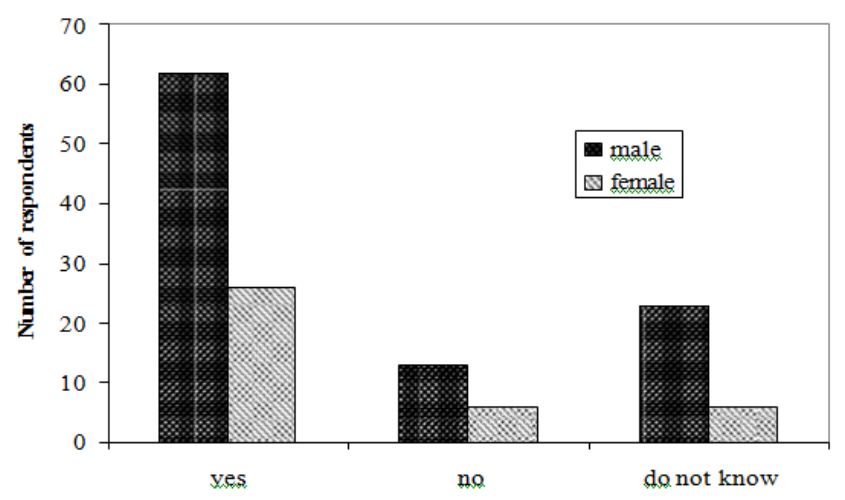

Figure 10. Effectiveness of the policies governing mangrove utilization

Table 5. A regression analysis of succession and utilization of mangroves along Mida

\begin{tabular}{llllll}
\hline & \multicolumn{1}{c}{ Ss } & df & \multicolumn{1}{c}{ Ms } & \multicolumn{1}{c}{ F } & \multicolumn{1}{c}{ P } \\
\hline Regression & 3424.753 & 1 & 3424.753 & 8.529 & 0.004 \\
Residual & 83521.747 & 208 & 401.547 & - & - \\
Total & 86946.500 & 209 & - & & \\
\hline
\end{tabular}

Note: Ss: Sum of squares, df: degree of freedom, Ms: Mean square, F: calculated f value, P: significant value R: Correlation between the observed and predicted values of the dependent variable 


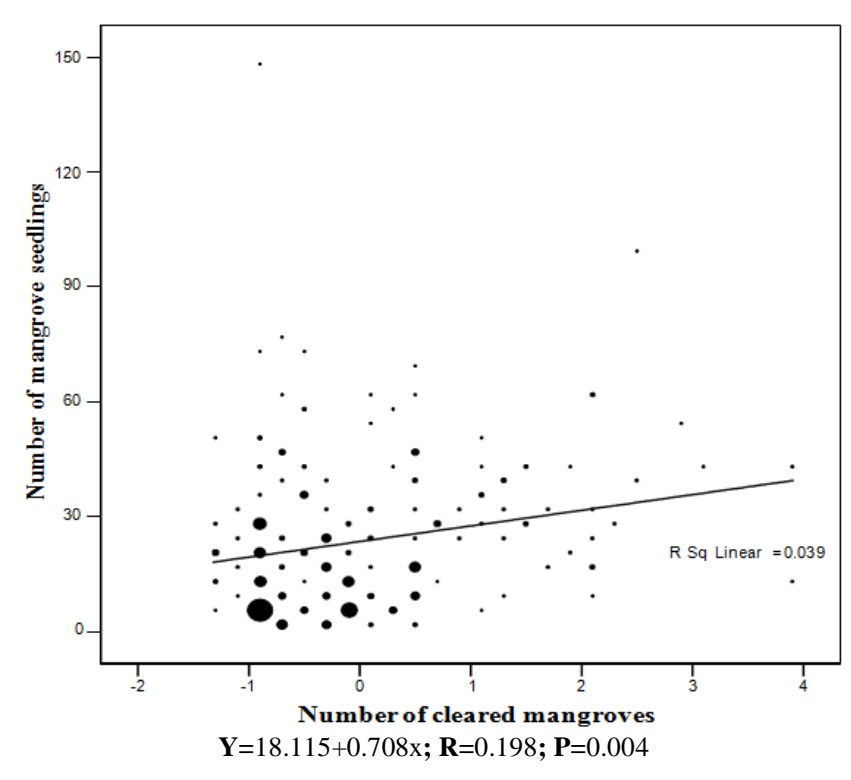

Figure 11. Scatter diagram of the relationship between the number of tree stumps and the number of seedlings at Mida Creek

Sonneratia alba was detected along the seaward forest boundary during the survey at Mida Creek, followed by mixed stands of Rhizophora mucronata and Ceriops tagal, Lumnitzera racemosa, Xylocarpus granatum, and Bruguiera gymnorrhiza. Then came the Avicennia marina (Figure 12).

According to the results of the interviews and observations, the roots, leaves, bark, and stem of several mangrove species are used in the following ways (Table 6):

The data show that mangrove stems are used more than leaves, roots, and fruits. This impacts succession since most mangrove species' embryos attach themselves to the stems of parent plants. When the stems are cut, the embryos fall and dry up, preventing natural succession. The mangrove ecosystem is home to fish, crabs, mollusks, crustaceans, and oysters, all consumed by the local populace. Fish is the primary source of protein for the people that live in that area. Thus, it is harvested daily. Some fishermen sell the fish they catch in the market to supplement their income. This money is used to purchase maize flour, other foods, and clothing. People tread on the seedlings of the mangrove species when gathering animal species, and they die. This has an impact on succession.

\section{Discussion \\ Utilization and accessibility}

Their accessibility determines the use of mangrove species. Avicennia marina is found near communities and is suitable for home use firewood; hence many mangroves have been cut for firewood in the nearby settlements, owing to the area's accessibility. Women who are terrified of going deep into the forest are the ones that do this. Most women work all day and can easily collect firewood when they get home in the evening. Because there is less water in the morning, firewood can also be easily obtained during low tides, which usually occur in the morning. The majority of mangrove cutters work at night, and because they cannot get far into the forest, they cut near communities. Mangroves gathered near communities are very easy to transport.

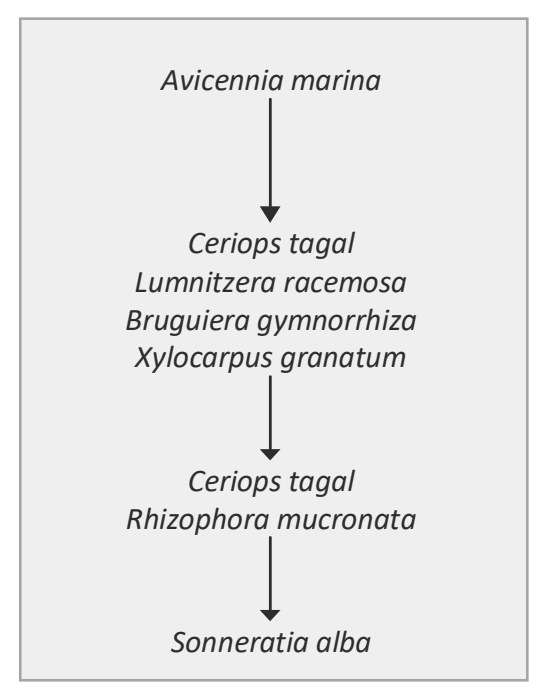

Figure 12. Successional and zonation trend of mangroves along Mida Creek, North Coast, Kenya

Table 6. Utilization of mangrove species by the local community at Mida Creek

\begin{tabular}{lll}
\hline Species name & Uses & Parts used \\
\hline Avicennia marina & Charcoal, low-quality firewood, & Stems \\
& Boat making, fencing posts, hive & Branches \\
Ceriops tagal & Poles, medium quality firewood, & Stems, bark \\
Rhizophora mucronate & Paddles, oars, dyes (tannings) & Stems of barks \\
& Charcoal, poles, dyes, medicines, & Stems and roots \\
Bruguiera gymnorrhiza & High-quality firewood, ointments & Stems \\
& High-quality firewood, charcoal, & Stems, fruits \\
Xylocarpus granatum & Oars, beehives paddles & Stems, leaves \\
Sonneratia alba & High-quality timber, charcoal, & \\
& Ointments, firewood & Stems \\
\hline
\end{tabular}


Because the area is difficult to access, only a few mangroves have been chopped in the middle. People find it difficult to walk in the middle due to the roots of Rhizophora mucronata and the thickness of the mangroves. Because of the stagnant water in the area, the earth is slippery (muddy clay soil) in the center, making it less accessible. Because the shoreline is easily accessible by boat, more trees have been felled near the water's edge. People can stroll freely in ocean arms during low tides, and they can readily reach the shorelines by cutting the mangroves they need to use. The boats can also transport harvested mangrove poles. Even though different needs of mangrove species are determined by accessibility rather than quality (Kairo 1995b), Rhizophora mucronata, Ceriops tagal, and Avicennia marina were preferred more than others, and this also impacts their utilization. Mangroves have zonation patterns due to individual species' environmental tolerance and physiological preferences (Rabinowitz 1975). Rhizophora mucronata can be found in the heart of the forest, and their knee roots render the area inaccessible. Each mangrove species has a variety of environmental tolerances (e.g., salinities, tidal floods, shade, land elevation, etc.) that limit it to the zones in which it thrives, e.g., the tropics. Ceriops tagal and Avicennia marina grow in the marginal dry landward side, whereas Sonneratia alba grows in the seaward fringe (Kairo 1995, Kairo 2001). Some mangrove species can be found on both the landward and middle side and the seaward side. People will leave the dwarf ones and go collect the huge ones in the seaward zone if the one on the landward side is dwarf and the same species is significant and is in the seaward zone, depending on the necessity. Depending on whatever mangrove species a person requires, they can travel as far as the seaward side to obtain it.

\section{Composition of mangrove forest}

Avicennia marina, Rhizophora mucronata, Ceriops tagal, Lumnitzera racemosa, Bruguiera gymnorrhiza, Sonneratia alba, Xylocarpus granatum, and Pemphis acidula are the mangrove species found at Mida Creek. Rhizophora mucronata, Ceriops tagal, and Avicennia marina are the most common species. Mangrove density, frequency, and dominance are used to make this determination. The mangrove forest in Mida Creek has been subjected to various degrees of human disturbance. Within the several species of mangroves, there were significant variances in frequency, density, and dominance. Anthropogenic factors such as indiscriminate and unregulated harvesting, pollution, and siltation have all impacted forest structure and composition.

\section{Changes in the mangrove forest cover}

Between 1992 and 2006, the mangrove vegetation in Mida Creek shrank by $6 \%$. This was based on aerial pictures processed to show changes between 1992 and 2006. Interviews and questionnaires were also undertaken to obtain the local community's perspectives on mangrove forest changes throughout time. Most people believe that mangrove vegetation in Mida Creek has diminished over time. Further investigation revealed that this was mostly the perspective of people who had lived in the area for more than five years and had witnessed changes in the mangrove forest during that time.

Licenses/permits were once issued in Mida Creek to cut mangrove trees. Still, this practice was discontinued when overuse of mangroves was discovered, and the forest was placed under the new administration. The main reason for the observed shift is a reduction in desired tree sizes or overall tree numbers owing to tree cutting and encroachment. The exploitation of the mangrove forest for sustenance and economic reasons has come from population growth and a scarcity of food. As the population grows, additional buildings are required, such as houses, boats, canoes, and oars for use while fishing for daily bread, necessitating the utilization of mangrove trees. The islands (Sudi and Kirepwe) have grown in size, and farming has begun, reducing forest area. People have turned to traditional medicine acquired from particular types of mangrove trees due to a lack of funds to go to the hospital and traditional beliefs. Another factor contributing to mangrove decline is high water pressure caused by the overharvesting of mangroves by the local people, which has resulted in the uprooting of trees along the shoreline, diminishing the extent of the forest, as seen in Kirepwe, where trees toppled owing to strong ocean currents. Unmanaged yet exploited mangroves do not permanently vanish, although they change over time. It suggests that small human societies cannot sustainably manage mangroves (Kairo et al. 2002).

\section{Mangroves preference}

Ceriops tagal, Rhizophora mucronata, and Bruguiera gymnorrhiza are three species that are preferred over others. Because of their capacity to grow long and straight, these species are preferred. Each of these species has a specific function inside the framework of a building, such as roofing poles, side framework, and lumber (DahdouhGuebas et al. 2000). Because of its high quality, Rhizophora mucronata is the most popular species. It is a durable wood resistant to termites and soil conditions such as wetness and saline soils, which is why most people choose it to build buildings. Their roots are often regarded for their medicinal powers against constipation, fertilityrelated (boosts human fertility), or menstruation diseases (relieves stomach aches) (Dahdouh-Guebas et al. 2000), which is why more women than men favor it. A medication made from the bark of the roots of Rhizophora mucronata is said to exorcise demons from those who are possessed. Rhizophora mucronata bark is used to make dyes, including tanning chemicals, which are applied to the insides of canoes and vessels and valued for their preservation properties. Dyes are also used to seal the microscopic holes of reed and palm leaf woven trays used for storing cereal flour and embellish weaving mats, baskets, and trays. It's used in schools to make tie-dye fabric garments. 
Insecticides are derived from Avicennia marina logs, which emit a large amount of smoke when burned, keeping mosquitoes and other biting night insects away. Simple one-person canoes are also created from the hefty wood of the Avicennia marina. Paddles and oars are constructed from Bruguiera gymnorrhiza or Rhizophora mucronata to drive boats forward. Because Ceriops tagal poles are thin, they are used as poles (fito) to create a network through the house's walls and roofs. Ceriops tagal is also used to construct shrines, cooking huts, livestock sheds, and pegs, among other buildings. Men are more focused on this work than women; thus, they prefer the species.

\section{Policies and effectiveness}

The interview/questionnaires revealed that illegal loggers destroy mangroves, but people/respondents were scared to name them for fear of being targeted. According to the respondents, the majority of the trees are harvested at night. Since most individuals do not harvest mangroves without permission, policies and legislation have been appropriately enforced. Those needing to construct poles must apply to the Kenya Forest Service for authorization to cut a certain number of poles for house construction (Pers comm., District Forest Officer, Gede). Some people take advantage of this to increase their crops. A management policy that consists of regulations and prohibitions in the absence of the instruments to apply them has been the greatest impediment to rational use and conservation of mangroves in Kenya (Ferguson 1993; Kairo 1995). It was evident that patrols in mangrove forests do not occur daily, therefore monitoring occurs only a few times per week. Because some areas within mangrove forests where unauthorized mangrove cutting occurs are inaccessible, patrol groups cannot visit them. Bans on all harvesting operations, for example, cannot be implemented effectively without first considering the effects for local subsistence populations. Some activities have emerged for the longterm utilization of mangroves, such as beekeeping by the Vimoyoni women's organization. The importance of mangroves has been taught. This type of environmental education instills in locals a sense of responsibility for their actions in the forest, but community-based natural resource management must be effectively institutionalized (Agrawal and Gibson 1999). Mangrove management in Kenya currently restricts the use of mangrove wood products for industrial fuelwood or charcoal. However, it is unclear how strictly the rule is enforced. Dahdouh et al. (2000) demonstrated how dangerous the situation might become if the government banned the cutting of mangrove timber. Several alternatives to mangrove cutting have been proposed (Kairo et al. 2002). However, it appears that the government provides few other options in return.

\section{Succession and utilization}

The forest conditions (cut or not cut), tides, and soil stability influence whether mangroves propagate by selfplanting or self-regeneration mechanisms. Harvesting too many trees from the forest reduces soil stability, causing propagules and saplings to be carried away by the tides and preventing natural succession. Because no propagules fall to become seedlings when the mother plant is cut, the number of seedlings that emerge is reduced, and some mangrove species may become extinct as a result. People trample on the tiny mangrove plants that occur when mangroves and other mangrove resources are being harvested, preventing them from germinating and affecting succession and trends. They also drag the mangrove poles across the ground when hauling them out of the forest, destroying the seedlings.

In conclusion, (i) The mangroves and their resources are extremely important to the residents of Mida Creek. (ii) The floral composition of the mangrove forest in Mida Creek has changed through time, reducing the size of the mangrove forest. This is due to the encroachment of the mangrove forest to perform various activities to support the local people in the area. (iii) Rhizophora mucronata is favored over other mangrove species due to its superior wood quality. (iv) In Mida, accessibility impacts how the mangroves are used. Mida Creek residents travel deep into the mangrove forest to gather the mangrove species. (v) Mangroves are impacted by human activity, altering succession patterns. (vi) Mangrove harvesting policies are ineffective since there are illegal mangrove cutters/harvesters because no licenses to exploit mangrove in Mida Creek are provided.

As a result of the findings of this study, the mangrove forest in Mida Creek has declined, and the subsequent efforts should be undertaken: (i) Mangrove replanting should be expanded to regions where it has not before been done. To provide young trees for replanting, more mangrove nurseries should be constructed. (ii) Environmental regulations are enforced to safeguard mangrove forests. (iii) More research on the succession/zonation of mangroves at the species level in Mida Creek is needed. This research should be carried out to compare artificial and natural mangrove regeneration. (iv) To prevent overexploitation of mangroves, sustainable utilization, such as beekeeping and crab farming, should be encouraged. The government should support local communities in obtaining resources to make this possible. (v) Educating and raising awareness about the value of the mangrove environment among the local people. This should be done at the school level so that the young ones can grow up with this knowledge. (vi) Monitoring unauthorized mangrove degradation as part of community participation in mangrove protection. To survive, the inhabitants need to plant different tree species, such as casuarinas.

\section{REFERENCES}

Agrawal A, Gibson CC. 1999. Enchantment and disenchantment: the role of community in natural resource conservation. World Dev 27 (4): 629-649. DOI: 10.1016/S0305-750X(98)00161-2.

Aizpuru M, Achard F, Blasco F. 2000. Global assessment of cover change of the mangrove forests using satellite imagery at medium to high resolution. In: EEC Research project no. 15017-1999-05 FIED ISP FR - Joint Research Centre, Ispra, Italy.

Brakel WH. 1979. Marine Parks and Recreation. In: World Bank Tourism Pricing Policy Study for Kenya, Ministry of Tourism and Wildlife, Kenya. 
Cannicci S, Burrows D, Fratini S, Lee SY, Smith TJ III, Offenberg J, Dahdouh-Guebas F. 2008. Faunistic impact on vegetation structure and ecosystem function in mangrove forests: a review. Aquat Bot 89 (2): 186-200. DOI: 10.1016/j.aquabot.2008.01.009.

Christensen B. 1983. Mangroves - what are they worth? Unasylva 35 (139): 2-15.

Cintrón G, Novelli S. 1984. Methods for studying mangrove structure. In: Snedaker SC, Snedaker JG (eds) The Mangrove Ecosystem: Research Methods. UNESCO, Paris, France.

Dahdouh-Guebas F, Koedam N. 2006. Empirical estimate of the reliability of the use of the Point-Centred Quarter Method (PCQM): solutions to ambiguous field situations and description of the PCQM protocol. For Ecol Manag 228 (1-3): 1-18. DOI: 10.1016/j.foreco.2005.10.076.

Dahdouh-Guebas F, Mathenge C, Kairo JG, Koedam N. 2000. Utilization of mangrove wood products around Mida Creek (Kenya) among subsistence and commercial users. Econ Bot 54 (4): 513-527. DOI: 10.1007/BF02866549.

Duke NC. 1992. Mangrove floristics and biogeography. In: Robertson AI, Alonghi DM (eds) Tropical Mangrove Ecosystems. Coastal and Marine Estuarine Series 41. American Geophysical Union, Washington, DC. DOI: 10.1029/CE041p0063.

FAO. 2003. New Global Mangrove Estimate. Food and Agriculture Organization, Rome.

FAO. 2005. Status and trends in mangrove areas extend worldwide. Working paper No. 64. Forest Resource Division. Food and Agriculture Organization, Rome.

FAO. 2007. The World's Mangroves 1980-2005. A thematic study prepared in the framework of the global forest resources assessment, Food and Agriculture Organization, Rome.

Ferguson W. 1993 A Land(scape) Ecological Survey of the Mangrove Resource of Kenya (Draft report) for the Forestry Department, Ministry of Environment and Natural Resources, Nairobi, Kenya.

Fisher AA, Laing JE, Stoeckel JE, Townsend JW. 2004. Handbook for Family Planning Operations Research Design. 2nd ed. Forest Department of Kenya (1983). Operational Cruise Reports on Lamu Mangroves, France.

Gang PO, Agatsiva JL. 1992. The current status of mangroves along the Kenyan coast: a case study of Mida creek mangroves based on remote sensing. Hydrobiologia 247 (1-3): 29-36. DOI: 10.1007/BF00008202.

Kairo JG, Dahdouh-Guebas F, Gwada PO, Ochieng C, Koedam N. 2002. Regeneration status of mangrove forests in Mida Creek, Kenya: a compromised or secured future? Ambio 31: 562-568. DOI: 10.1579/0044-7447-31.7.562.

Kairo JG, Gwada PO. 1998. Mangroves of Mida Creek, Kenya. In: Mwatha GK, Fondo E, Uku J, Kitheka JU (eds) Biodiversity of Mida Creek: Final Technical Report, Nairobi, Kenya.

Kairo JG. 1995a. Artificial Regeneration and Sustainable Yield Management of Mangrove Forests at Gazi Bay, Kenya. [Thesis]. University of Nairobi, Nairobi, Kenya.

Kairo JG. 1995b. Community Participatory Forestry for Rehabilitation of Deforested Mangrove Areas of Gazi Bay (Kenya). A First Approach. Final Technical Report. University of Nairobi, Nairobi, Kenya.

Kairo JG. 2001. Ecology and Restoration of Mangrove Systems in Kenya. [Dissertation]. Vrije Universiteit Brussel, Brussels, Belgium.
Kennedy A. 1988. Mida Creek-A Study of Human Impact. [Thesis]. University of Edinburgh, Scotland, U.K.

Kokwaro J. 1985. The distribution and economic importance of the mangrove forests in Kenya. J E Afr Nat Hist Soc 75: 1-10.

Kristensen E, Bouillon S, Dittmar T, Marchand C. 2008. Organic carbon dynamics in mangrove ecosystems: a review. Aquat Bot 89 (2): 201 219. DOI: $10.1016 /$ j.aquabot.2007.12.005.

MacNae W. 1968. A general account of the fauna and flora of mangrove swamps and forests in the Indo-West Pacific region. Adv Mar Biol 6: 73-270. DOI: 10.1016/S0065-2881(08)60438-1.

Manohar S. 1993. Utilization and Management Perspectives for the Mangrove Forest Reserves of Kenya. National Workshop for the Improved Management and Conservation of the Kenyan Mangroves. Ministry of Environment and Natural Resources, Kenya.

Nagelkerken I, Blaber S, Bouillon S, Green P, Haywood M, Kirton LG, Meynecke JO, Pawlik J, Penrose HM, Sasekumar A, Somerfield PJ. 2008. The habitat function of mangroves for terrestrial and marine fauna: a review. Aquat Bot 89 (2): 155-185. DOI: 10.1016/j.aquabot.2007.12.007.

Ouko EM, Manohar S. 1998. Mangrove conservation and management: a structural regime for the Kenyan coastline. In: Hoorweg J (ed) Dunes, groundwater, mangroves, and birdlife in coastal Kenya. ACTS Nairobi 4: 97-110.

Rabinowitz D. 1975. Planting experiments in mangrove swamps of Panama. In: Walsh G, Snedaker S, Teas H (eds) Proc of mt Symp on Biol and Manag of Mangroves. Honolulu. Hawaii, Oct. 8-11. 1974.

Ruwa RK, Polk P. 1986. Short communication: Additional information on mangrove distribution in Kenya: some observations and remarks. Kenya I. Sci Ser B 7: 41-45.

Ruwa RK. 1993. Zonation and distribution of creek and fringe mangroves in the semi-arid Kenyan coast. In: Lieth H, Al Masoom AA (eds) Towards the rational use of high salinity tolerant plants. Tasks for Vegetation Science, Vol 27. Springer, Dordrecht. DOI: 10.1007/97894-011-1858-3_9.

Saenger P, Hegerl EJ, Davie JDS. 1983. Global Status of Mangrove Ecosystems. Commission on Ecology Papers No. 3. Switzerland, World Conservation Union (IUCN), Gland.

Semesi AK. 1998. Mangrove management and utilization in Eastern Africa. Ambio 27 (8): 620-626.

Spalding MD, Blasco F, Field CD. eds. 1997. World Mangrove Atlas. The International Society for Mangrove Ecosystems, Okinawa, Japan.

Tomlinson CB. 1986. The Botany of Mangroves. Cambridge Tropical Biology Series, Cambridge University Press, Cambridge, New York.

UNEP/IUCN. 1988. Coral Reefs of the World, Vol.2: Indian Ocean, Red Sea and Gulf. United Nations Environment Programme, Regional Seas Directories and Bibliographies. International Union for Conservation of Nature, Gland.

Van Der Werf GR, Morton DC, Defries RS, Olivier JGJ, Kasibhatla PS, Jackson RB. 2009. $\mathrm{CO}_{2}$ Emissions from forest loss. Nat Geosci 2 (11): 737-738. DOI: 10.1038/ngeo671.

Walters BB, Ronnback P, Kovacs J, Crona B, Hussain S, Badola R, Primavera JH, Barbier EB, Dahdouh-Guebas F. 2008. Ethnobiology, socio-economics and adaptive management of mangroves: a review. Aquat Bot 89 (2): 220-236. DOI: 10.1016/j.aquabot.2008.02.009. 